Article

\title{
Implementation of a Mobile Web-Based Information Sharing Forum Information System
}

\author{
Muhamad Muslihudin ${ }^{1}$, Miftahuddin ${ }^{2}$, Kanti Lestari ${ }^{3}$ \\ 1,2,3 Information Systems Study Program, STMIK Pringsewu, Lampung \\ 1,2,3 Jalan Wisma Rini No. 09 Pringsewu, Lampung, Indonesia
}

\begin{tabular}{l}
\hline SUBMISSION TRACK \\
\hline Recieved: Aug 21, 2020 \\
Final Revision: Sept 18, 2020 \\
Available Online: Sept 29, 2020 \\
KEYWORD \\
\hline Internet, Information Systems, Mobile Web, \\
Website, Forum \\
CORRESPONDENCE \\
\hline Phone: 0729-22240 \\
E-mail: mmuslihudin415@gmail.com \\
\hline
\end{tabular}

A B S T R A C T
The mobile web-based knowledge sharing forum
information system is one of the media that utilizes the
internet as a means of gathering and discussing to exchange
information for people who want to share their knowledge
with people who have not yet studied. With this forum, the
public can find out which regions are still taking a lot of
education and can make organizations so that they can share
their knowledge with the community. The process of
creating a mobile web-based knowledge sharing forum
information system by analyzing an existing system using
the SDLC method. Mobile web-based knowledge sharing
forum information system is one of the media that utilizes
the internet as a means of gathering and discussing to
exchange information for internet users who want to share
their knowledge with people who have not yet studied

received education or for those who have dropped out of school. using a smartphone.

According to Fachruddin (2016). In his research, he produced a community information system prototype for web-based JOTHI Jambi that could be further implemented to produce a community information system that could be implemented in an organization. The community information system prototype provided services in the form of information from the JHOTI Jambi organization. Where the discussion forum includes visitor discussions, member discussions, as well as criticism and suggestion services[2]. According to Victor Yuliyanto, Christine Dewi (2016), his research resulted in a knowledge sharing discussion forum application where after testing, it was found that the existence of a web-based knowledge sharing as a medium for discussion to share knowledge with the Indonesian people in areas that have not yet 
application can support and can be used as a media for subject documentation. [3].

This research forum is made based on mobile web so that users can easily access the forum to share knowledge with smartphones, forum design uses the SDLC method, by using this method researchers can find it easy to analyze the needs used and the ease in designing the forum application.

Based on the description of the problem above, the researcher created a forum for a place to gather and discuss for people or users who want to share their knowledge with people in areas who have not received education or who have dropped out of school and invite other people to share their knowledge, this forum was created in the form of a mobile web so that it is easily accessible and more structured when opened using a smartphone With this forum, the community or users can exchange information about areas that will be targeted to share knowledge, and can work together in forming a team when going into the field.

\section{THEORETICAL BASIS}

\section{A. Information Systems Concept}

According to Kadir (2014), an information system is a framework that coordinates resources (humans, computers) to convert input (input) into output (information), in order to achieve company goals.[4].

According to Henry C Lucas (1982: 35), which is translated by Jugianto HM, states that the information system is an activity of organized procedures, when executed it will provide information to support decision making and control within the organization.[5].

\section{B. Forum}

Forum is a forum or a meeting place for a community that has the same interest and purpose to freely exchange ideas on topics or issues related to the forum. In the large Indonesian dictionary forum is a noun which means 1) institution or body; container, 2) congregation, 3) meeting place to exchange ideas freely.[6] Meanwhile, according to the Cambridge Dictionary forum is a situation or meeting where people can talk about problems, especially those of the public's interest or concern[7]

\section{Definition of Science}

According to the Big Indonesian Dictionary (KBBI), science is defined as a knowledge about a field that is systematized according to certain methods, which can be used to apply certain symptoms in the field (knowledge), such as law, education, economics. etc.[8] According to $\mathrm{J}$. Hababer (1972) Science is a result of human activity which is a collection of theories, methods, and practices and becomes an institution in society.

\section{Website}

According to Jhonsen (2004: 5) Website (Web Site) is a collection of web pages related to other files that are related. In a website, there is a page known as the home page. The home page is a page that is first seen when someone visits a website. From the home page, visitors can click on the hyperlink to move to another page on the website[9][10]

\section{E. Web Mobile}

The mobile web is a collection of browser-based html pages. which can be accessed using portable devices such as smartphones and gadgets or tablets. via the internet or telecommunications network in the form of $3 \mathrm{G}, 4 \mathrm{G}$, or wifi. This mobile web is designed to display text or image, audio and video data content or a combination of some content on the 
screen of a smartphone and of course also influenced by screen size limitations and the type of touch screen.[11] - [13]

\section{METHODS}

\section{A. Method of collecting data}

The data used in this study are as follows:

1. Observation Method

At this stage the researchers conducted direct observations in the Tanggamus area by looking at the community education and seeing the activeness of the community in using information technology to obtain the required data.

\section{Literature Method}

At this stage the researchers carried out the library method obtained from references from previous journals and books. In this literature method, the researcher studies and summarizes the references obtained.

\section{B. Systems Development Method}

According to Muhammad Muslihudin and Oktafianto (2016) the SDLC method (System Development Life Cycle, System Life Cycle) or Systems Life Cycle, in systems engineering and software engineering, is the process of creating and modifying systems and models and methodologies used to develop these systems. In software engineering, the SDLC concept underlies many types of software development methodologies. These methodologies form a framework for planning and controlling the creation of information systems, namely the software development process. SDLC is also a pattern taken to develop a software system, which consists of the following stages: plan (planning), analysis (analysis), design (design), implementation (implementation),[14].
1. Plan (planning)

At this stage the researcher will design the system and system requirements such as system modeling design, database and mobile web design design.

2. Analysis (Analisys)

At this stage the researcher analyzes the hardware and software requirements to be used.

\section{Design (Design)}

At the design stage of this research, the researcher determines the design of the mobile web-based knowledge sharing forum, in this case the researcher uses DFD (Data Flow Diagram) as a system design for the forum, then the researcher also uses the HTML and PHP programming languages to create a structure and appearance. Forum, The database used in this forum is the MySQL database.

4. Implementation (Implementation)

The implementation at this stage is the series or creation of a knowledge-sharing forum that has gone through the previous stages, at this implementation stage the forum will be based on a mobile web or appear responsive which will make it easier to access using a smartphone.

5. Testing

At this stage the researcher will test the mobile web-based knowledge sharing forum that has been made to suit the system's requirements.

\section{Processing (maintenance)}

At this stage the researcher evaluates the results obtained by the application of the mobile webbased information sharing forum system. During that time, maintenance was carried out on the mobile web that had been made, so that 
the mobile web forum did not experience a problem.

\section{Research Framework}

This research framework explains the stages of research, based on the flowchart above, the research starts with the identification and determination of the title, then the next stage is to determine the aims and objectives of the research, after this stage is complete, it continues into the research method, in this research method there are two stages, namely the method. data collection and system development methods, in data collection methods used observation methods and literature methods. After this stage is completed, the next stage is design design, in this stage the researcher determines the entire design that will be used for making the system, after determining the design design, then the next stage of system implementation,

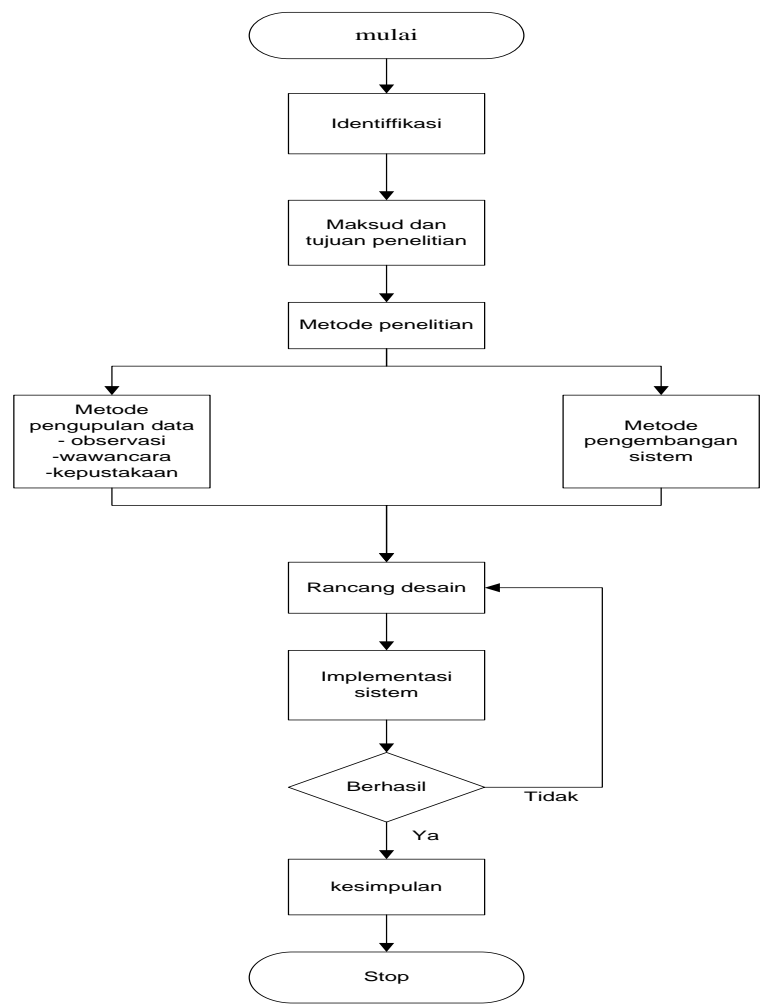

Figure 2. Research framework chart

IV. RESULT

\section{A. System Design Using DFD}

This section explains the context diagram of the knowledge sharing forum. The context diagram itself describes the overall process in the knowledge sharing forum system. And also explains the relationship between the system and external entities which include users and admins.

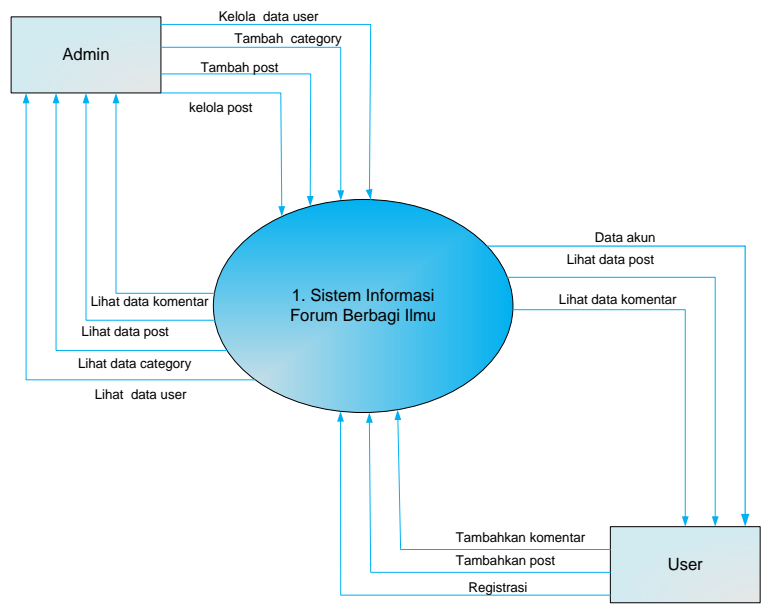

Figure 3. Context diagram

This section explains DFD level 1, which is where the data flow process is shown in more detail with 9 processes including admin login, user registration, user data management, user login, category data management, post data management, comment data management, post admin data management, and manage admin comment data.

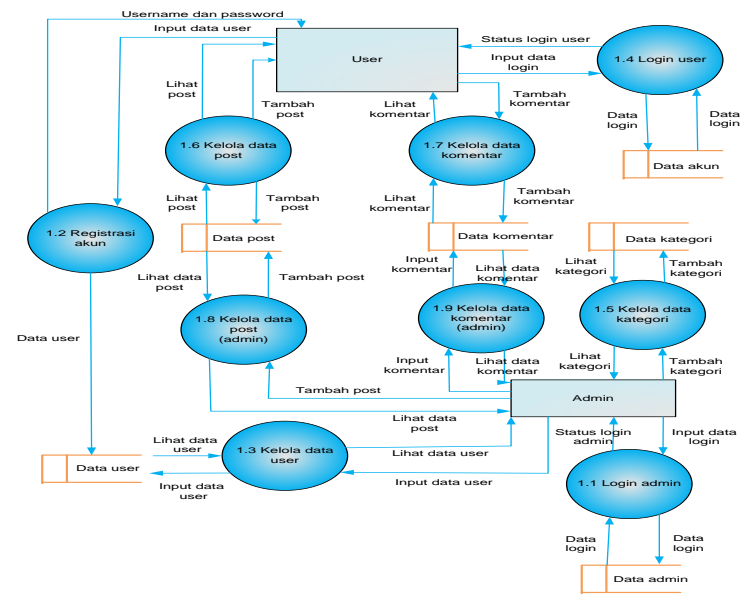

Figure 4. DFD level 1 
This section describes DFD level 1 from the more detailed post user data management process which includes user login, post data input and see the list of posts.

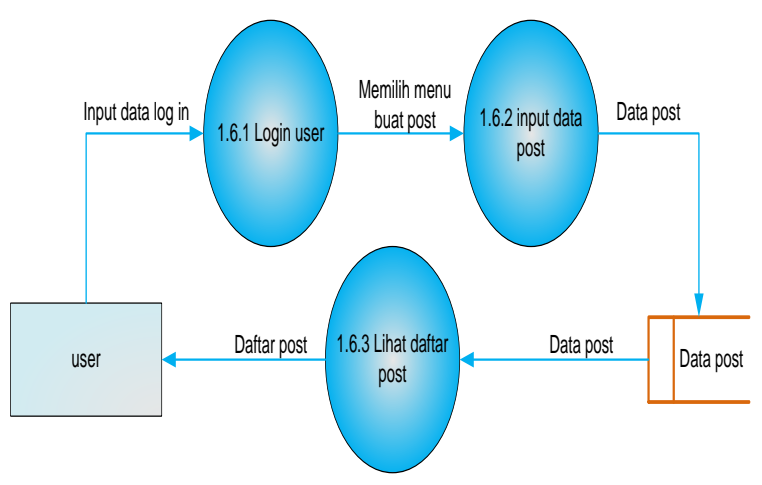

Figure 5. DFD level 1 manage post user data

DFD level 1 is a more detailed post admin data management process which includes admin login, post data input, see list of posts and delete post data.

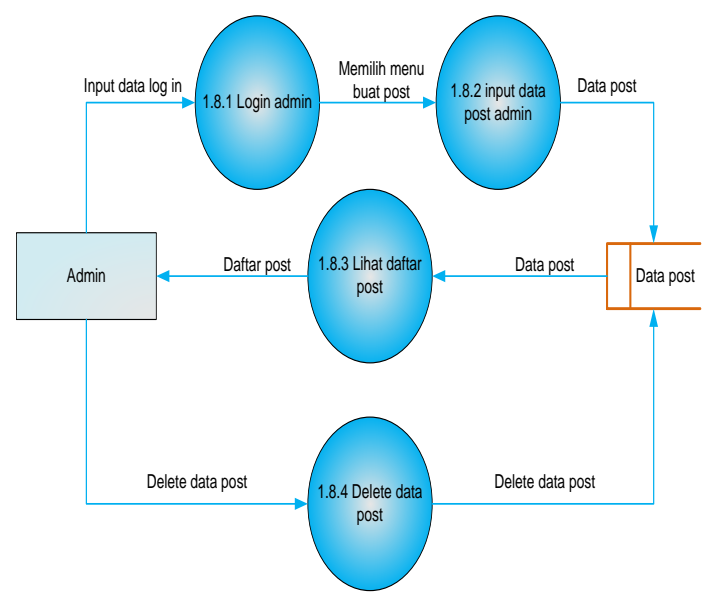

Figure 6. DFD Level 1 Manage Post Admin Data

The data relation for the knowledge sharing forum can be drawn as shown below.

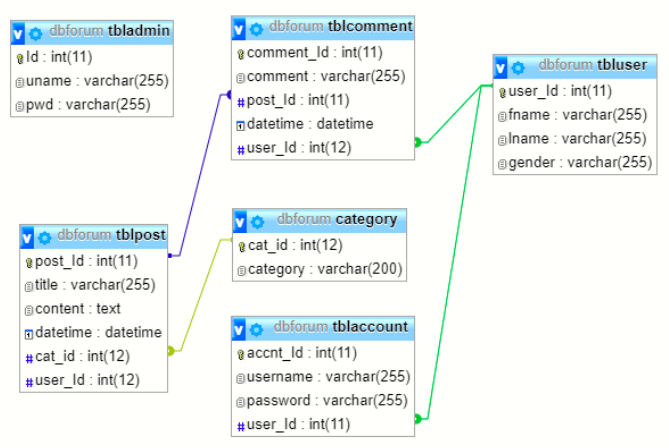

Figure 8. Data relations

\section{F. Interface Design}

In this section there is a form containing the username and password for admin login.

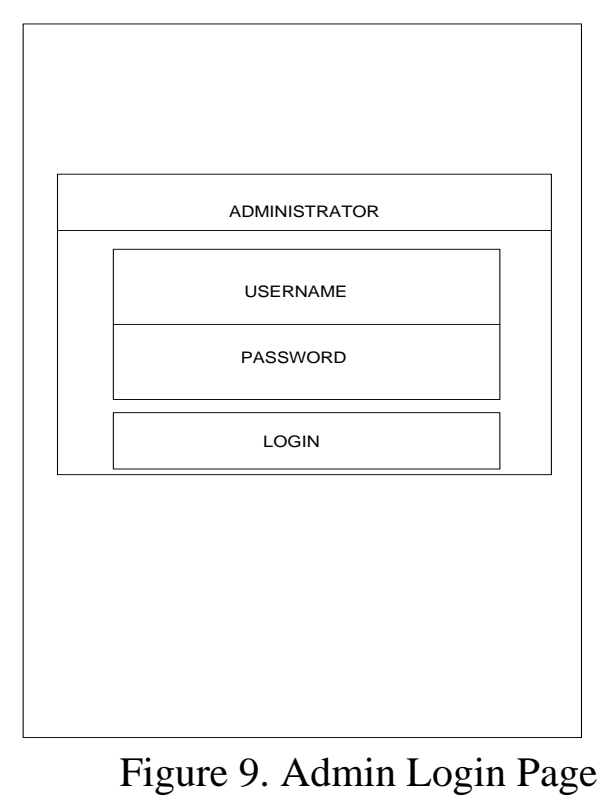

Furthermore, in the Adamin menu there is a navigation menu and the name of the website in the header section, then there is a list of posts that admin can read by selecting the detail button. 


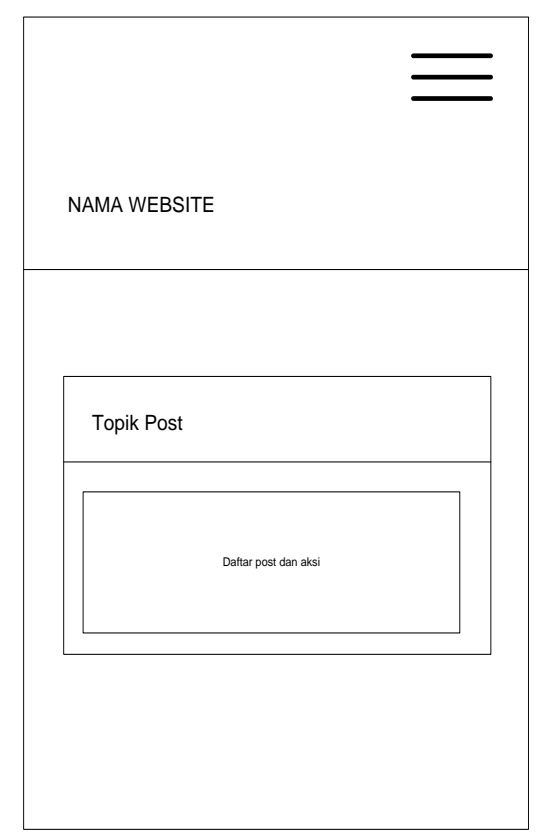

Figure 10. Admin home page

In this section, the navigation menu and the name of the website are placed in the header section, as well as the registration form for the user.

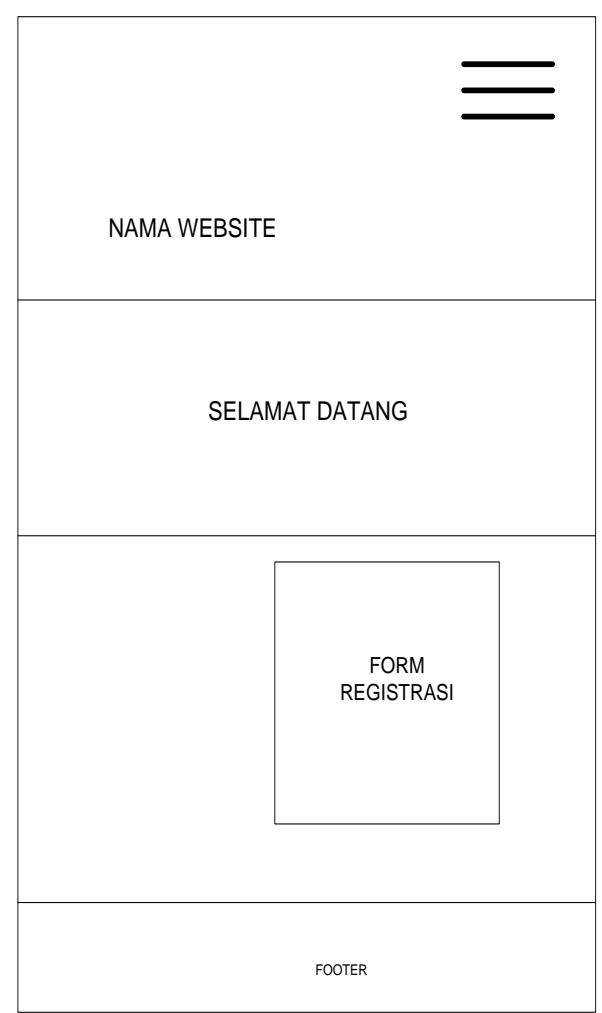

Figure 10. The user's main page

\section{G. Implementation}

This login page is the beginning when a user opens the website. On this page, users who don't have an account can register on this initial page

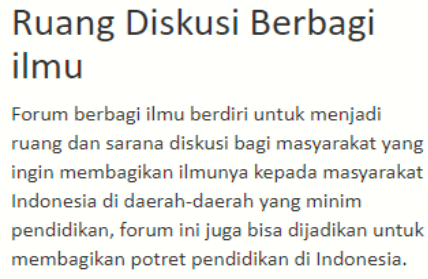

Ruang Diskusi Berbagi ilmu

Forum berbagi ilmu berdiri untuk menjadi ruang dan sarana diskusi bagi masyarakat yang ingin membagikan ilmunya kepada masyarakat Indonesia di daerah-daerah yang minim pendidikan, forum ini juga bisa dijadikan untuk membagikan potret pendidikan di Indonesia.

\begin{tabular}{|l|}
\multicolumn{1}{|c|}{ Registrasi } \\
\hline Nama Depan \\
\hline Nama Belakang \\
\hline Jenis Kelamin \\
\hline Username \\
\hline Password \\
\hline Registrasi \\
\hline
\end{tabular}

Figure 11. User start page and registration form on the initial page

The navigation menu can be opened by selecting the button in the upper right corner of the website, this menu contains the user login form after registration to enter the knowledge sharing forum. 


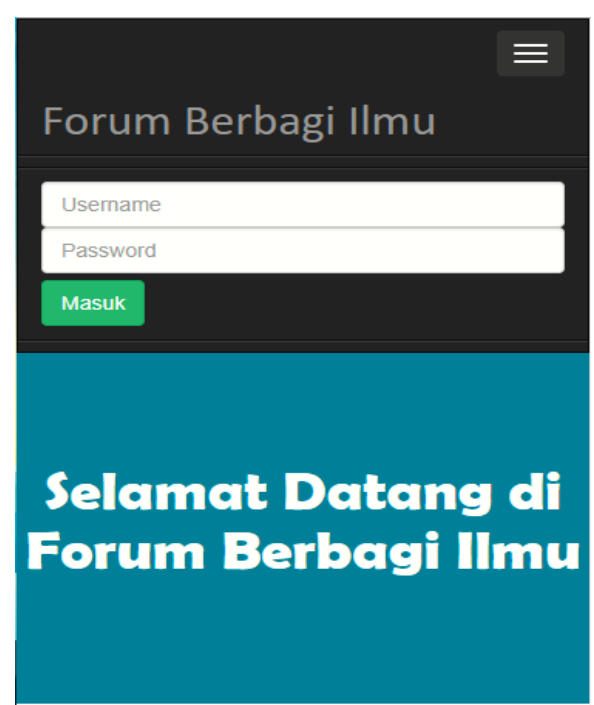

Ruang Diskusi Berbagi ilmu
Figure 14. User Home Page And Navigation Menu After Login

On this page the user can create posts according to existing categories.

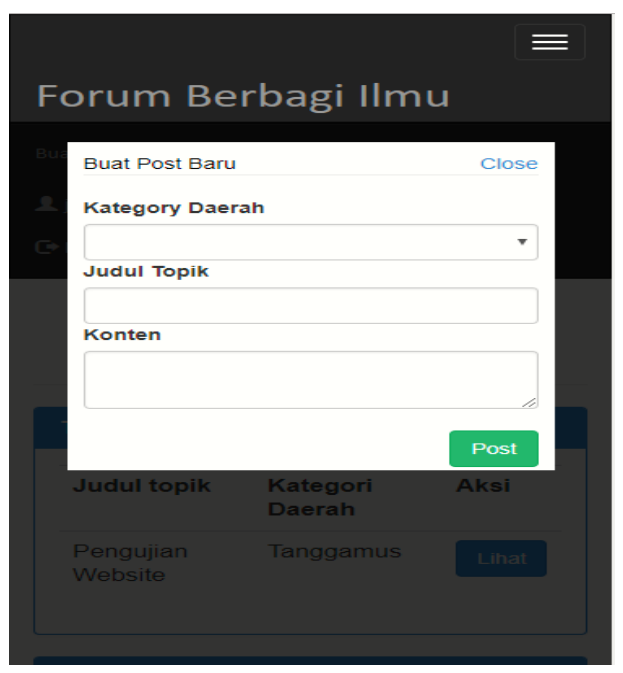

Figure 15. Creating a Post page

On the in page the user after seeing another user's post on the home page can respond by entering a comment into the post. also comment on other user's posts posted by selecting the view button. On this page there is also a navigation menu where there is an option to create posts for the user and the option to log out.
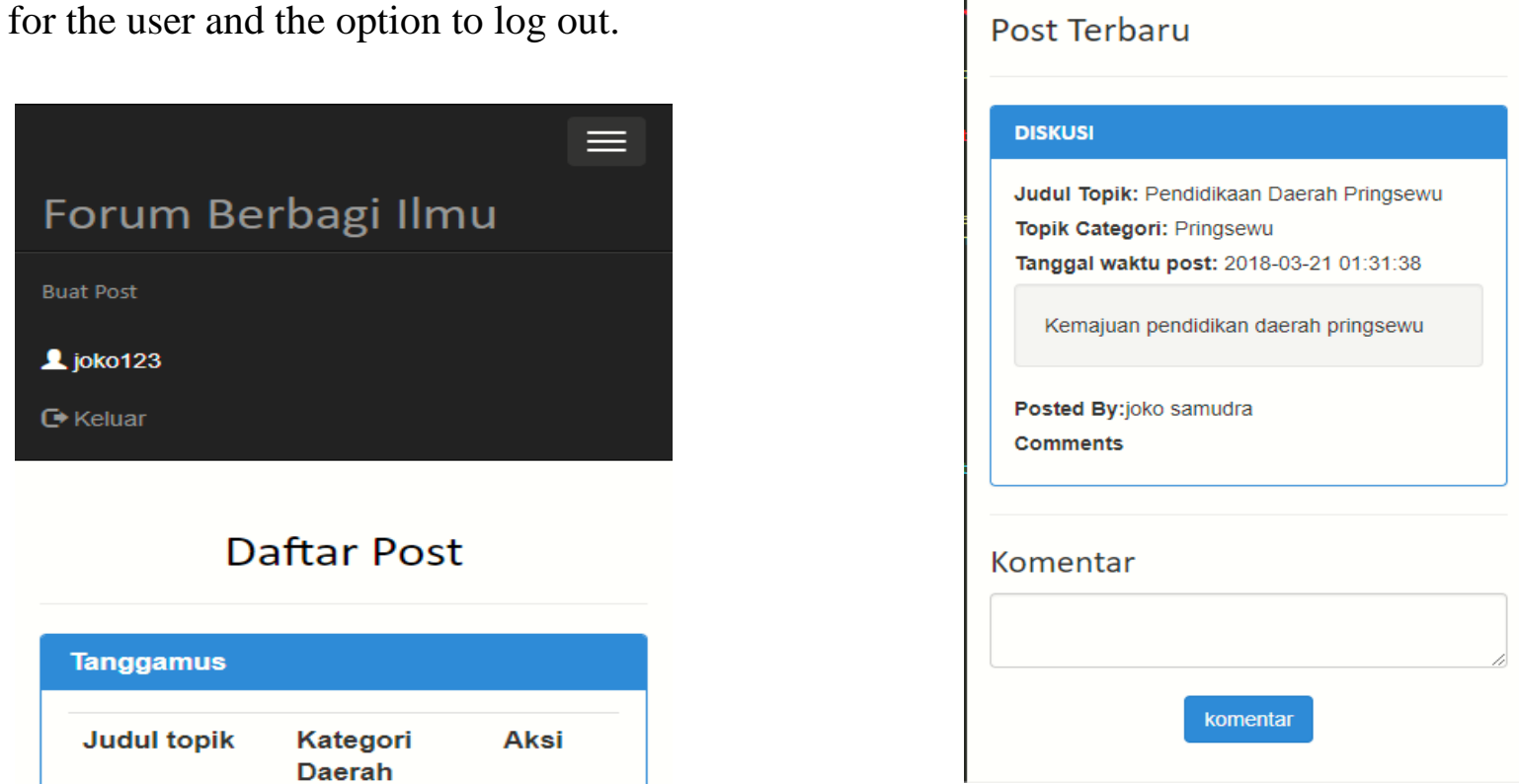

\begin{tabular}{|lll|}
\hline Tanggamus & & \\
\hline Judul topik & $\begin{array}{l}\text { Kategori } \\
\text { Daerah }\end{array}$ & Aksi \\
\hline $\begin{array}{l}\text { Pengujian } \\
\text { Website }\end{array}$ & Tanggamus & Lihat \\
\hline
\end{tabular}

Figure 16. Comment page 
This Admin Home page is the page after logging in using the admin account. On this page the admin can see posts from users that will automatically appear on the page and can manage existing posts.

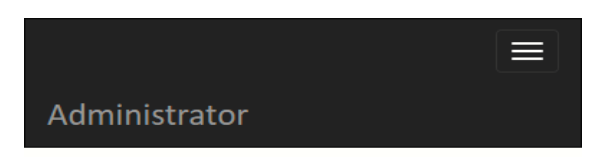

Dashboard

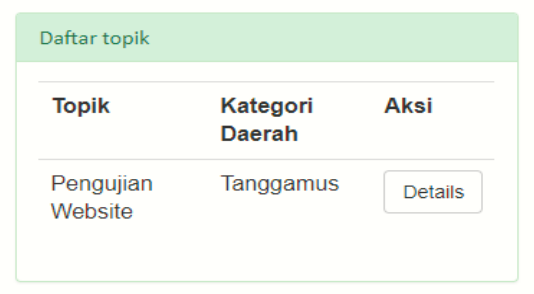

Figure 17. Admin home page

In this admin navigation menu, admins can see the admin menu which can manage and manage user accounts and user post topics, and can add regional categories to be included in this website forum.

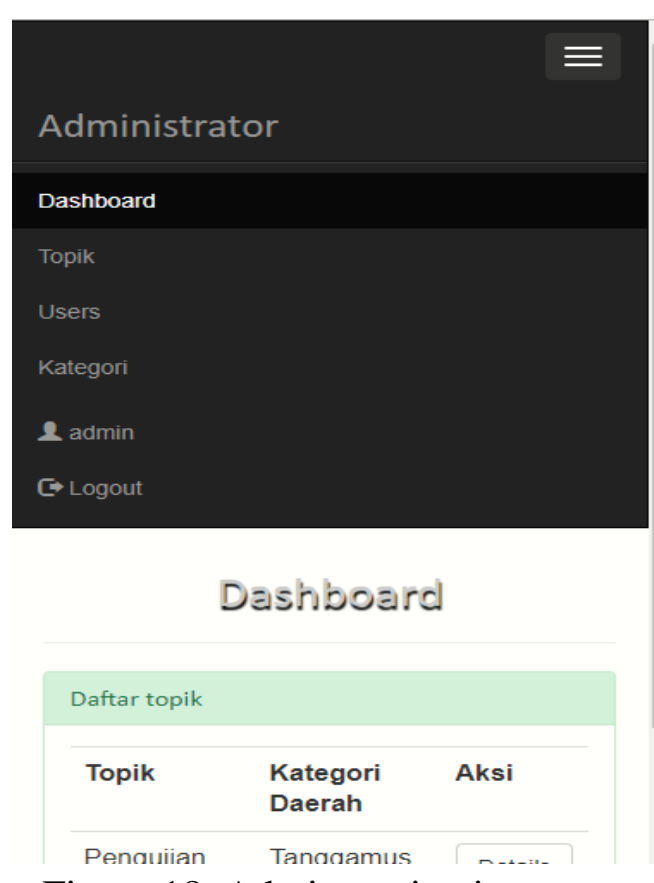

Figure 18. Admin navigation menu

\section{CONCLUSION}

From the results of the discussion, it can be concluded that the creation of a mobile web-based knowledge sharing forum information system using HTML and MySql databases is easy to access because the forum supports smartphone display so it is more effective and efficient. The mobile webbased information sharing forum information system is one of the media that utilizes the internet as a means of gathering and discussing to exchange information for internet users who want to share their knowledge with people who have not yet taken education.

\section{THANK-YOU NOTE}

We would like to express our gratitude to the Startect Education Foundation and STMIK Pringsewu who have funded the Internal Higher Education Research for the 2019 Funding Year. And thanks to LPPM STMIK Pringsewu who always provides directions in each stage of the research carried out. 


\section{References}

[1] Kominfo, "Top 25 Countries, Ranked by Internet User, 2013-2018," Kompas.com, Thing. 1, 2018.

[2] Fachruddin, "Analysis and design of webbased community information systems for jothi jambi," J. SISFO, vol. 7, no. 1, pg. 1-19, 2013.

[3] VYC Dewi, "Designing a Discussion Forum as a Media Knowledge Sharing in SMA Negeri 2 Salatiga Using the Yii Framework," 2016.

[4] A. Kadir, Introduction to Information Systems. Yogyakarta: Andi Offset, 2014.

[5] J. Hartono, Information Technology Systems: Integrated Approach: Basic Concepts, Technology, Applications, Development, and Management, 2nd ed. Yogyakarta, 2009.

[6] "Definition of Forum," https://kbbi.kemdikbud.go.id/entri/forum, 2016.

[7] "Meaning Of 'Forum' In English Dictionary," https://dictionary.cambridge.org/dictionary/e nglish/forum. .

[8] "Understanding https://kbbi.kemdikbud.go.id/entri/ilmu, 2016.

[9] DE Hendrianto, "Making a Website-Based Library Information System at the Donorojo 1 State Junior High School, Pacitan Regency," vol. 3, no. 4, pg. 57-64, 2014.

[10] F. Satria, WEB programming (HTML, CMS and JavaScript). Yogyakarta: Andi Offset, 2016.

[11] AYM Agam Alpharesy, Zuzy Anna, "Analysis of Income and Expenditure Patterns of Household Fishermen Workers in the Kampak Coastal Area of West Bangka Regency," J. Perikan. and Kelaut., vol. 3, no. 1, pg. 11-16, 2012.

[12] R. Syafitra, "Design and Development of Web and Android Based Academic Guidance Applications in Management Study Program S1 STIE MDP," p. 1-10.

[13] MF Alfarizi and S. Ipnuwati, "The Mobile Web-Based Senior High School Subject
Scheduling Application in SMA Negeri 2 Pringsewu," J. Inf. and Komput., vol. 6, no. 1, pg. 1-5, 2018.

[14] O. Muhammad Muslihudin, Analysis and Design of Information Systems Using Structured Models and UML. Yogyakarta: Andi Offset, 2016.

Muhamad Muslihudin, is a permanent lecturer in the STMIK Pringsewu information system study program, Lampung, apart from being a lecturer, he remains active in various seminars and becomes the Journal Editor Team in various universities and government agencies.

Miftahuddin,is an active student of the STMIK Pringsewu information system study program, Lampung. Apart from being students, he is active as a member of the STMIK Pringsewu lecturer research team.

Kanti Lestari, Is a Postgraduate student IIB Darmajaya majoring in Informatics Engineering and is an Administrative Staff of STMIK Pringsewu, Lampung Indonesia 